\title{
Tailored Functional Recipe (TFR) Approach to Delay the Progression of HIV to AIDS among People Living with HIV (PLWH) in Abuja, Nigeria
}

\author{
Abraham Mainaji Amlogu1,2*, Sundus Tewfik³ , Charles Wambebe4, Kate Godden1, \\ Ihab Tewfik ${ }^{1}$ \\ ${ }^{1}$ School of Life Sciences, University of Westminster, London, UK \\ ${ }^{2}$ State House Medical Centre, Abuja, Nigeria \\ ${ }^{3}$ School of Human Sciences, Faculty of Life Sciences, London Metropolitan University, London, UK \\ ${ }^{4}$ Ahmadu Bello University, Zaria, Nigeria \\ Email: ${ }^{*}$ abraham.amlogu@my.westminster.ac.uk, amloguab@yahoo.com
}

Received 2 August 2014; revised 1 September 2014; accepted 9 September 2014

Copyright (C) 2014 by authors and Scientific Research Publishing Inc.

This work is licensed under the Creative Commons Attribution International License (CC BY). http://creativecommons.org/licenses/by/4.0/

(c) (i) Open Access

\section{Abstract}

Background: HIV/AIDS is a pandemic disease and its scourge has had a devastating impact on health, nutrition, food security and overall socioeconomic development in affected countries. Moreover, intervention programmes, which simply employ antiretroviral drugs, have been found to lack effectiveness particularly when the patient is under-nourished. Aim and Purpose: This presented pilot intervention provides evidence that suggests use of local resources as therapeutic nutrition. This can act as a fundamental part of the comprehensive package of care at the country level. Methodology: Local ingredients, which were known for their availability, accessibility, micro and macro-nutrient strengths were selected and optimised into a nutritional functional meal (Amtewa). Daily consumption was ascertained to assess its effects on nutritional status and biomedical indices of the study participants $(n=100)$ who were/were not taking Highly Active Anti-retroviral Therapy (HAART). Findings: Mean CD4 count for ART-Test group at baseline and sixth months increased by $40.8 \mathrm{cells} / \mathrm{mm}^{3}$ while the ART-Control group decreased $18.12 \mathrm{cells} / \mathrm{mm}^{3}$. This positive outcome qualified Amtewa meal to the next phase of intervention (400 participants) to ascertain its effectiveness on health status of HIV infected subjects and appraise its position within the National Health Services framework as innovative approach to attenuate the progression of HIV to AIDS in Nigeria. Conclusion: Amtewa-based approach in HIV management is innovative, culturally relevant, reliable and requiring low technology in order to assure compliance, sus-

\footnotetext{
"Corresponding author.
} 
tainability and cost effectiveness. Although the achieved results take the form of specific technology, it suggests that a prolong consumption of the intervention meal (Amtewa) will be suitable to sustain the gained improvements in MUAC and CD4 cell counts thereby slowing the progression of the disease.

\section{Keywords}

\section{HIV, AIDS, CD4 Count, Macro and Micronutrients, ART, Nutritional Functional Meal, Sustainability}

\section{Introduction}

Human Immunodeficiency Virus (HIV) is a severely infectious and fast replicating retro-virus which impairs and deteriorates the functioning of the immune system's cell [1]-[4]. Since 2007, Sub-Saharan Africa (SSA) has remained the region most heavily affected by HIV/AIDS across the world, accounting for $67 \%$ of all people living with HIV and for 75\% of AIDS deaths [4]-[6]. The HIV/AIDS scourge has had a devastating impact on health, nutrition, food security and overall socioeconomic development in countries that have been greatly affected by the disease. There is an urgent need for renewed focus on and use of resources for nutrition as a fundamental part of the comprehensive package of care at the country level [7]-[11]. Action and investment to improve the nutritional status of People Living with HIV/AIDS (PLWHA) should be based on sound scientific evidence, local resources, and programmatic and clinical experience with the prevention, treatment, and management of the disease and related infections [12]-[14]. Although there are gaps in scientific knowledge with respect to Tailored Functional Recipes in the management of HIV, much can and should be done to improve the health, nutrition and quality of care for PLWHA and their families and communities [15]-[17].

The effects of under-nutrition on the immune system are well documented and include decreases in CD4 T cells, suppression of delayed hypersensitivity and abnormal B-cell responses [18]. Interestingly, the immune suppression caused by protein-energy malnutrition mechanism is similar in many ways to the effects of HIV infection in PLWH as illustrated in Figure 1 [19] [20].

An earlier review by Piwoz and Preble [21] examined preliminary evidence that improving nutrition status may improve some HIV-related outcomes. HIV infection increases energy requirements through increases in resting energy expenditure (REE 12\% higher), while reduced food intake, nutrient mal-absorption, negative nitrogen balance and metabolic alterations exacerbate weight loss and wasting, perpetuating the cycle [22]-[25]. Increase in REE may be due to the production of tumor necrosis factor-alpha and/or interleukin $l$ in patients with AIDS. However, potential mechanisms of wasting invoked in AIDS patients and their impact on energy intakes (e.g., severe oral and/or esophageal candidiasis, viral esophagitis or extensive oral kaposis sarcoma) are

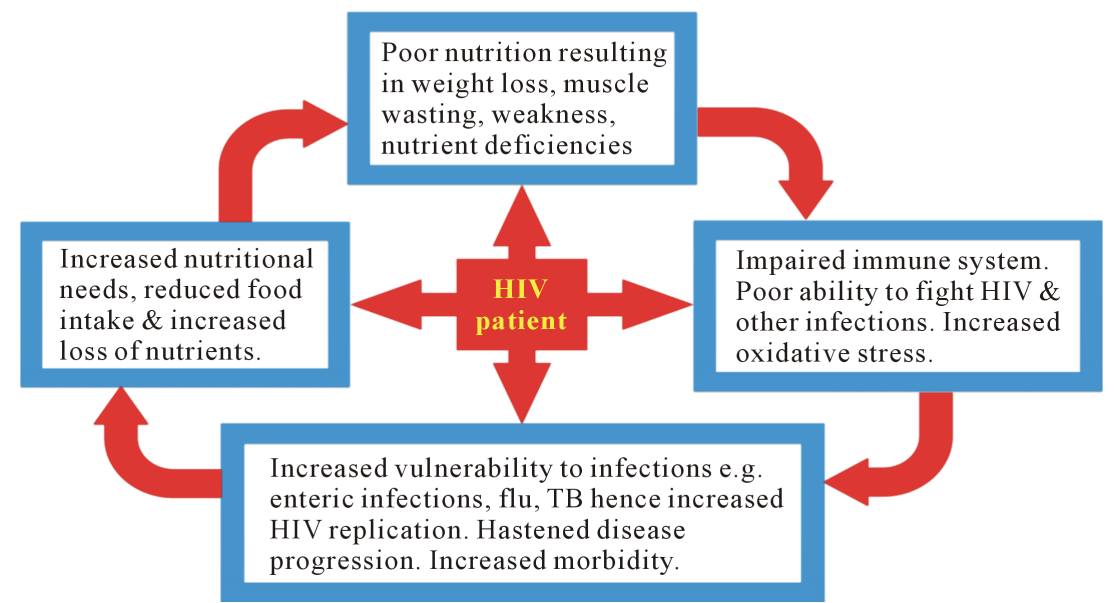

Figure 1. The vicious cycle of malnutrition in the HIV patient (source: RCHQC and FANTA 2003). 
perhaps more relevant. Anorexia can occur in response to systemic infection or mental depression, and intestinal mal-absorption, increased loss of nutrients; muscle wasting and weakness were also reported in AIDS [22].

\subsection{Additional Energy Requirements (Asymptomatic vs. Symptomatic)}

Asymptomatic HIV-positive adults' need 10\% additional energy (per day) compared to HIV-negative individuals of the same sex [26]. The energy requirement for symptomatic HIV positive adults is $20 \%$ to $30 \%$ (per day) higher than for HIV-negative individuals of the same sex while children with growth faltering require $50 \%$ to $100 \%$ additional energy [26]-[28]. Therefore, macro and micronutrients from naturally occurring (as opposed to synthetics with lower bioavailability) components tailored to meet the additional energy requirements of PLWHA will enhance well-being and health and/or reduce the risk of disease or provide health benefit so as to improve their quality of life [4] [29].

\subsection{Justification for HIV Nutrition Intervention Programme in Nigeria}

Antiretroviral (ARV) drugs have been shown to reverse under-nutrition in HIV/AIDS but are usually used at the later stages of the disease when the patients are moribund [30] [31]. Presently, 75\% of Nigerians infected with HIV as recommended by WHO do not require ART $\left(\mathrm{CD} 4 \geq 350\right.$ cells $\left./ \mathrm{mm}^{3}\right)$, but should receive nutritional assistance to maintain the immune system, sustain healthy levels of physical activity and for optimal quality of life [9] [14] [32]. Incidentally, in Nigeria virtually all the HIV/AIDS programmes and interventions at the moment focus on the $25 \%$ of HIV infected subjects that require ART (CD4 $<350$ cells $/ \mathrm{mm}^{3}$ ) [33]. The implication of the current situation is that all the interventions at the moment are grossly unable to cope with the treatment of those who require ARVs urgently, hence the need for a nutrition intervention in HIV care. In essence, this study proposed a nutrition intervention programme which was designed to address under-nutrition of the $75 \%$ of PLWH who do not require ART (and sustain their CD4 count level $\geq 350$ cells $/ \mathrm{mm}^{3}$ i.e. not require initiation of ART) and equally support the $25 \%$ who are receiving ART treatment (CD4 count $\geq 200$ cells $/ \mathrm{mm}^{3}$ ).

Therefore, the focus of this intervention was to develop an optimised meal containing macro and micro nutrients from natural food sources in Nigeria employing the tailored functional recipe (TFR*) concept (as defined below) to strengthen the immune system of PLWH.

\subsection{Definition of *TFR}

Food that is naturally occurring, accessible, affordable and perhaps consumed in unnatural concentrations as part of the usual diet and has demonstrated physiological and or biomedical benefits in reducing the risk of chronic disease beyond basic nutritional functions [4] [14].

\subsection{Aim and Objectives}

Aim: To assess the effectiveness of a public health-nutrition intervention programme to delay the progression of HIV to AIDS among people living with HIV in Abuja, Nigeria.

Objectives: The objectives of the study were:

1) To assess the quality and quantity of specific macro/micronutrients in local vegetables and grains consumed by People Living with HIV/AIDS and compare these values with age-specific recommended intakes.

2) To optimise a nutritionally functional meal (Amtewa) that contains known concentrations of macro and micronutrients to be employed in the intervention.

3) To assess the nutritional status and biomedical indices prior and post the intervention (baseline vs. end point; with follow-up at three and six months interval).

4) To evaluate the effectiveness of Ametwa meal in delaying the progression of HIV to AIDS.

\section{Study Design and Methodology}

\subsection{Description of Study Setting and Formulation of Amtewa Meal}

The setting of the study was the State House Medical Centre Abuja (SHMCA), Nigeria. SHMCA is a secondary health institution recognized by the Federal Government of Nigeria for the care and management of PLWH. Presently, the institution is involved in intervention programmes such as Voluntary Counseling and Testing 
(VCT), Prevention of Mother to Child Transmission of HIV (PMTCT), Paediatric Antiretroviral Treatment (PAT) and Adult Antiretroviral Treatment (AAT).

Ethical approvals were obtained from SHMCA and University of Westminster, London, the two centres where the field work and laboratory analysis/investigations were carried out.

\subsubsection{Food Sampling Techniques to Avoid Variability in the Values of the Proximate Analysis}

Seasonality and variability of the nutritional composition of single food items were taken into consideration in the collection of TFR ingredients. Representative samples $(n=4)$ were subjected to proximal analysis. Each sample was washed, irrelevant extraneous matter removed by sieving, sedimentation and flotation methods and then drained before drying in an oven heated at $78^{\circ} \mathrm{C}$ for 60 hours. Dried samples were size reduced with an electric blender to fine, free-flowing powders. Aeration of the samples during the blending process was avoided by allowing 60 seconds of break from every 60 seconds of the blending process.

\subsubsection{Proximate Analysis}

Laboratory analyses of macronutrients (such as, Soxhlet method for fat extraction) were carried out in the laboratories of University of Westminster, London while other macro and micronutrient analyses (such as: Kjeldahl method for protein analysis; inductively coupled plasma method for analysis of minerals) were conducted at the Science Centre of the London Metropolitan University.

\subsubsection{Formulation of Amtewa Meal}

Based on WHO recommendations on additional energy requirements for asymptomatic (10\%) and symptomatic (20\% - 30\%) PLWH and the EARs energy for male $(2500 \mathrm{kcal} / \mathrm{d})$ and female $(2000 \mathrm{kcal} / \mathrm{d})$, the average EARs was calculated as $2250 \mathrm{kcal} / \mathrm{d}$. Since PLWH were advised to continue with their normal daily diet; an average of $10 \%-20 \%$ additional energy for both asymptomatic and symptomatic PLWH was calculated (354.92 kcal/d). This additional energy (354.92 kcal/d) was formulated and provided in a $100 \mathrm{~g}$ sealed pack of Amtewa meal. The $100 \mathrm{~g}$ Amtewa meal containing $50 \mathrm{~g}$ soya beans, $15 \mathrm{~g}$ moringa leaves, $15 \mathrm{~g}$ of carrot roots and $20 \mathrm{~g}$ of millet was dispensed to PLWH for daily consumption (up to 6 month) as illustrated in Figure 2.

\subsubsection{Measurements}

Anthropometric, Biochemical indices and clinical trial were undertaken at State House Medical Centre Abuja (SHMCA) Nigeria, one of the centres in Nigeria accredited for the care and management of HIV/AIDS patients.
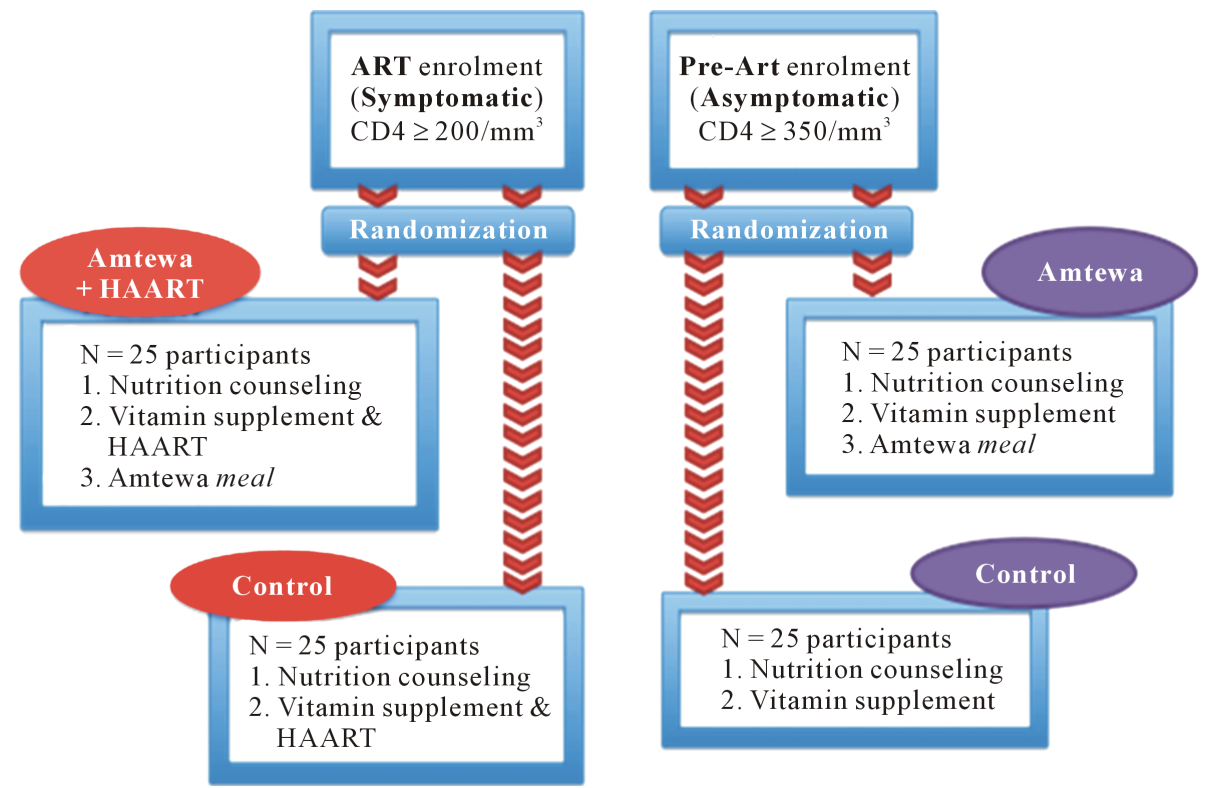

Figure 2. Illustrating the two arms of study design (Symptomatic vs Asymptomatic) and showing the patients on Amtewa meal, Amtewa + HAART versus their controls. 


\subsubsection{Sensory Evaluation Test}

Three variations of Amtewa meal: Amtewa meal A (310 kcal/d), Amtewa meal B (354.92 kcal/d), Amtewa meal $\mathrm{C}(385.40 \mathrm{kcal} / \mathrm{d})$ were prepared according to the direction of use on the packaging. Seven participants in different cubicles (booth) were served with Amtewa meal A, B and C each in a glass cup for consumption to determine their preference in terms of colour, taste, smell and texture. Six of the participants selected Amtewa meal B (354.92 kcal/d) as their preferred formula.

This represents $85.71 \%$ preference compared to Amtewa meals A and C.

\subsection{Target Population}

All patients who assess Antiretroviral treatment at the State House Medical Centre, Abuja, Nigeria between February 2002 and December 2010 were given opportunity to participate in the research. Demographic characteristics such as age, gender, occupation, marital status, number of spouses, past history of STIs, and blood transfusion were obtained from the patients. Recruitment of study participants was done by the researcher while the sample collection, CD4 count and other laboratory investigations (Total protein, SGOT, RG, PCV) were performed by a trained laboratory scientist in SHMCA.

Eligible (PLWH with a CD4 count of $\geq 200$ cells $/ \mathrm{mm}^{3}$, above 18 years, not pregnant and without HIV/AIDS complications) subjects were recruited (based on CD4 count records obtained from the medical records department and were allocated appropriately into one of four groups as illustrated in Figure 2) and given the right to decline participation without jeopardizing receipt of care at the State House Medical Centre, Abuja. Prior intervention, project information and consent forms were read/interpreted and signed by all the study patients.

Once enrolled, patients were subjected to an assessment tool which includes anthropometric and biomedical indices. Study participants continued standard treatment for PLWH by the SHMC (nutritional counseling, vitamin supplements) and half of each arm (Pre-ART and ART) were provided with Amtewa meal for daily consumption for six months.

At the onset of the study, one hundred $(n=100)$ patients were recruited. The justification of the sample size for the pilot study is based on the 95\% confidence interval and a precision limit of 0.05 for the study.

\subsection{Design (Pilot) of the Public Health-Nutrition Intervention Programme}

The design of the study consisted of four consecutive steps:

Step 1: See Figure 2.

- ART (Anti-Retroviral Therapy) enrolment are People Living With HIV (PLWH) and are on HAART with a CD4 count value of $\geq 200 / \mathrm{mm}^{3}$ according to WHO classification and HIV treatment guideline in Nigeria. These patients are HIV patients but not full-blown AIDS patients.

- Pre-ART enrolment are People Living With HIV (PLWH) but are not on HAART yet because their CD4 count value is $\geq 350 / \mathrm{mm}^{3}$ according to WHO classification and HIV treatment guideline in Nigeria.

- Nutrition Counseling is provided as a routine service to People Living With HIV/AIDS (PLWH) receiving care at the SHMCA.

- Vitamin supplements** are provided, prescribed and dispensed at a dose of one capsule daily or one capsule twice daily to PLWH receiving care at the SHMCA.

- HAART (Highly Active Anti-Retroviral Therapy) are HIV medicines provided, prescribed and dispensed (according to the clinical status of the patient) to PLWH receiving treatment at SHMCA.

- Amtewa meal is a combination micro and macro-nutrients, carefully selected from locally available food in Abuja Nigeria, analyzed and formulated into a 100 g pack for daily consumption by study subjects. The composition of Amtewa meal is Soya beans (Glycine max), millet (Pennisetumtyphoides), Carrot (Daucuscarota), Moringa leaves (Moringaoleifera).

\footnotetext{
Box 1. Vitamin supplements**.

Vitamin supplements**: The composition of the vitamin supplement (per capsule per day) is vitamin A 3333 IU, vitamin B1 $4.5 \mathrm{mg}$, vitamin B2 5.1 mg, vitamin B6 6 mg, vitamin B12 6 нg, vitamin C 180 mg, vitamin D3 200 IU, vitamin E 10 mg, Biotin 0.3 mg, Pantothenic Acid $21 \mathrm{mg}$, Folic Acid $0.2 \mathrm{mg}$, Nicotinamide $57 \mathrm{mg}$, Calcium $50 \mathrm{mg}$, Magnesium $40 \mathrm{mg}$, Phosphorus $50 \mathrm{mg}$, Copper $0.4 \mathrm{mg}$, Iron $3.6 \mathrm{mg}$, Manganese $0.5 \mathrm{mg}$, Zinc $3 \mathrm{mg}$, Chromium $10 \mu \mathrm{g}$.
} 
Step 2. Anthropometric measurements (BMI, MUAC) and biomedical indices (CD4 count, PCV, TP, RG, SGOT) for all the groups (Pre-ART and ART) at month zero (0) i.e. the beginning of the study.

Step 3. Re-assessment of anthropometric (BMI, MUAC) and biomedical indices (CD4 count, PCV, TP, RG, SGOT) for all the groups (Pre-ART and ART) at three (3) months and six (6) months.

Step 4. Comparison of results obtained from Steps 2 and 3.

\section{Research Variables and Statistical Analysis}

Anthropometric measurements (BMI, MUAC) and biomedical indices (RG, TP CD4 count, SGOT, PCV) were conducted at the commencement of the study and in the third and sixth months. All collected assessment tools were revised for completeness and data analysed using SPSS statistical software. Simple frequencies were used for data checking. Also, simple descriptive statistics was used for summary of quantitative data and frequencies for qualitative data. Bivariate relationships were displayed in cross tabulations, i.e. the association of nutritional intervention on CD4 count. Univariate group comparisons included chi square tests for proportion and Student's $\mathrm{t}$ tests for continuous variables.

\section{Results}

\subsection{Proximate Analysis}

Of the four (soya bean, millet, carrot and moringa leaves) samples analysed, $50 \mathrm{~g}$ of soya bean seeds contained the highest amount of CHO (17.5 g), protein (20 g) and fat (10 g) while $20 \mathrm{~g}$ of the millet seeds contained 14.98 $\mathrm{g}$ of $\mathrm{CHO}, 1.58 \mathrm{~g}$ of protein and $0.64 \mathrm{~g}$ of fat. These two samples formed the bulk of the macronutrients and therefore $70 \%$ of Amtewa meal. Also, the four samples contained micronutrients [vitamins A (from carotene), B, C; Ca; Mg; K; Na; Mn; Fe; Cu; Zn; Se and phosphorus] which are essential to boost immunity. Soya bean seed and moringa leaves contained higher amounts of micronutrients than carrot and millet, however, carrot contained $2.2 \mathrm{mg}$ of carotene, which is a natural source of vitamin A. The total weight of each sample was compared to the DRV and RNI for the United Kingdom (UK) for the macro and micronutrients [34] to ensure that the summation of each micronutrient does not exceed the DRV and RNI. UK values were used because the DRV for the Nigerian population has not been determined. According to DRV for UK, the EARs energy per day for male is $2500 \mathrm{kcal} / \mathrm{d}$ and for female is $2000 \mathrm{kcal} / \mathrm{d}$ (average $2250 \mathrm{kcal} / \mathrm{d}$ ). The optimised $354.92 \mathrm{kcal} / \mathrm{d}$ of Amtewa meal, which is $15 \%$ to $20 \%$ of the average daily energy requirements for healthy male and female adultswas packaged and dispensed to PLWH to be consumed in addition to their normal daily nutritional intake.

\subsection{Patients' Follow-Up (Baseline, Three Months and Six Months)}

\subsubsection{Anthropometric Measurements}

Median increase in MUAC of participantsin the Pre-ART group (with Amtewa) was 3.4\% while for the ART group (with Amtewa), it was 7.8\%. On the other hand, control groups (without Amtewa) for both Pre-ART group and ART group had a decrease in their median MUAC by $0.8 \%$ and $3.7 \%$ respectively. Similarly, Figure 3 shows that the mean MUAC for Pre-ART (with Amtewa) group increased by 3.25\% while mean MUAC of ART (with Amtewa) group, increased by $5.58 \%$ after six months. This is statistically significant $(P=0.05)$.

\subsubsection{Immune Status}

Median CD4 count of patients on Pre-ART group with Amtewa decreased by 13 cells $/ \mathrm{mm}^{3}$ (statistically significant) while ART group with Amtewa increased by 43 cells $/ \mathrm{mm}^{3}$. Also, patients in the control group (Pre-ART without Amtewa) maintained a median CD4 count $\left(599 \mathrm{cells} / \mathrm{mm}^{3}\right.$ ) while the ART control group (without Amtewa), CD4 count decreased by 11 cells $/ \mathrm{mm}^{3}$. Similarly, mean CD4 count for Pre-ART with Amtewa meal group increased by $0.69 \%$ and ART group with Amtewa meal, CD4 increased by $9 \%$ (Figure 4). This indicated clinical and statistically significant differences between the two groups of participants on the meal and those without the meal.

\subsubsection{Clinical End Points}

Results of other biomedical indices (random glucose test; packed cell volume; total protein and serum glutamic oxaloacetic transaminase) showed values within the normal range; e.g. normal range of glucose 140 - 200 


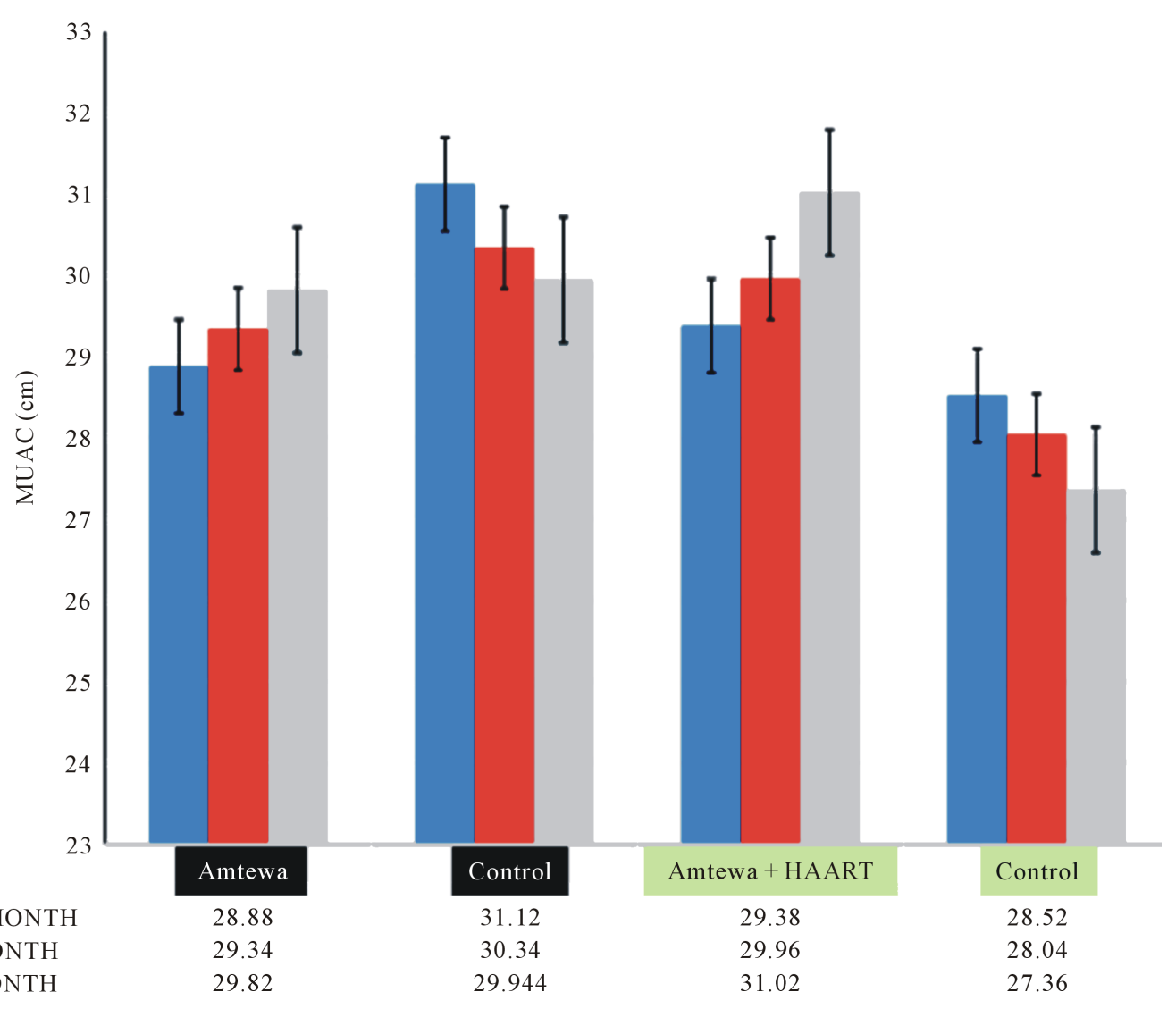

- MUAC@ZEROMONTH

- MUAC@3RD MONTH

-MUAC@6THMONTH

29.34

31.02

Figure 3. Bar chart showing the impact of Amtewa meal on MUAC $(\mathrm{cm})$ of study patients $(\mathrm{n}=100)$.

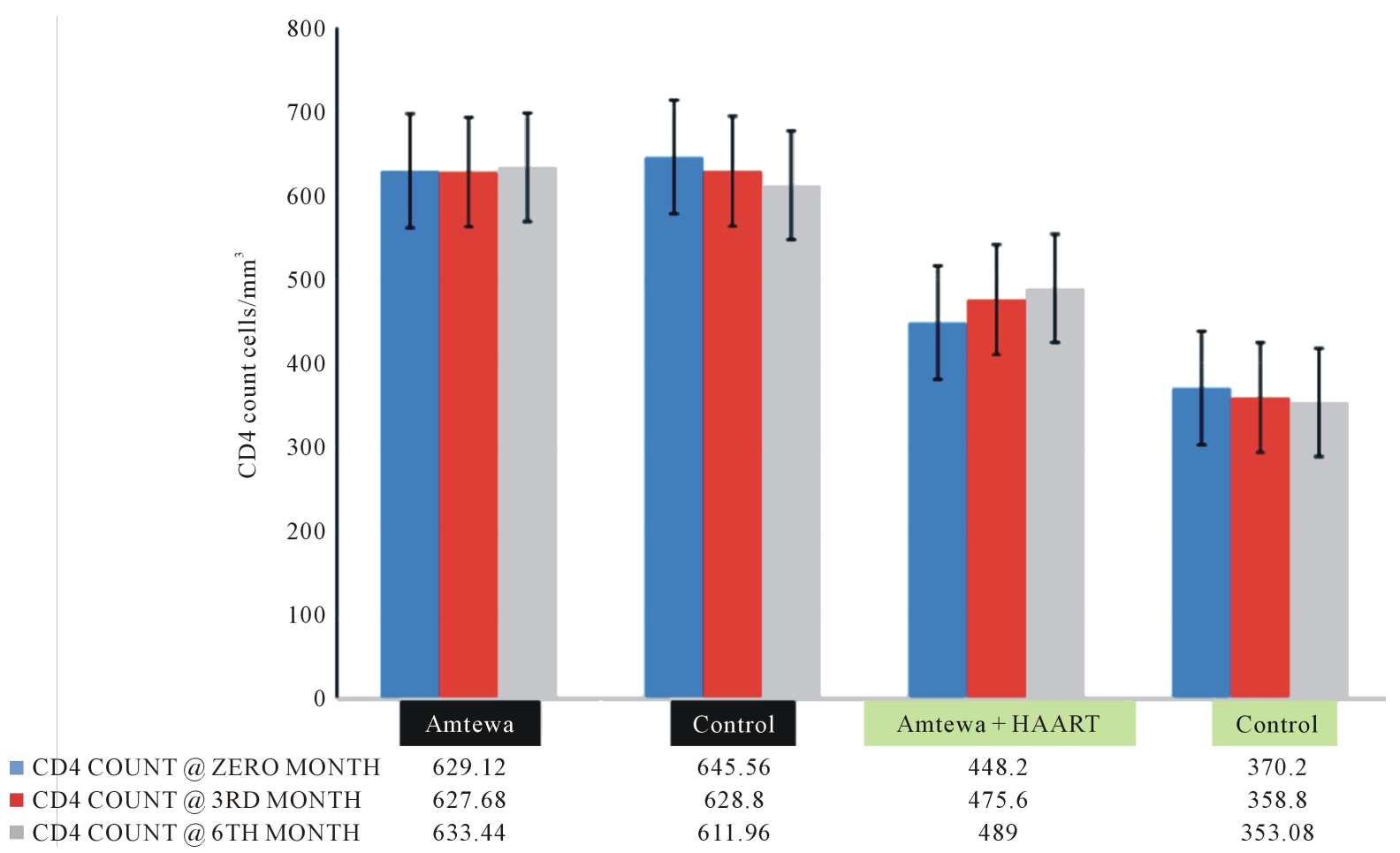

Figure 4. Bar chart showing the impact of Amtewa meal on CD4 (count cell/ $\left./ \mathrm{mm}^{3}\right)$ of study patients $(\mathrm{n}=100)$. 
$\mathrm{mg} / 100 \mathrm{ml}$; packed cell volume normal values $40 \%$ female and $45 \%$ male; normal range of total protein 60 - 83 g/100ml and normal range of SGOT 0 - 12 I.U/L.

\section{Discussion}

This pilot study described 100 PLWH out-patients ( $>18$ years) that were divided into four groups of 25 each (see Figure 2). $59 \%$ were female while $41 \%$ were male. $55 \%$ were married, $34 \%$ single, $7 \%$ widow and $4 \%$ widower. Fifty (50) of this PLWH were monitored for their adherence to ART and Amtewa meal (354.92 kcal per day) intervention versus their control $(n=50)$ for the duration of three and six months from April 2011 to December, 2011.

\subsection{CD4 Counts}

Comparison of results obtained at 0 and 6 months suggests that in two Test groups (Pre-ART and ART) on the Amtewa meal:

- Median CD4 lymphocyte count of Pre-ART Test group decreased by 2.3\% whiles the count for the ART Test group increased by $10.8 \%$.

- Mean CD4 count of Pre-ART Test group however had an increase of $0.69 \%$ while ART Test group increased by $9 \%$. This increase is statistically significant $(P=0.05)$ compared to the control groups (Pre-ART and ART).

The effect of Amtewa meal was more pronounced in patients on HAART than those on non-HAART, as indicated by increased CD4 count. This is in line with the results obtained by Paton et al. [35], who studied the impact of malnutrition on the survival and the CD4 count response in 394 HIV patients starting ART. $P=0.03$ for HAART compared with non-HAART treatment, This study supports Paton et al.'s conclusion that malnutrition at the time of starting ART was significantly associated with decreased survival of the CD4 cells.

Furthermore there was a decrease in the mean and median CD4 cell count of Pre-ART and ART groups of the controls (see Figure 2 and Figure 4). Kaiser et al. [36] similarly demonstrated a mean absolute CD4 count increase by an average of 65 cells in the micronutrient group versus a 6-cell decline in the placebo group at 12 weeks.

\subsection{Middle Upper Arm Circumference-MUAC}

Median and Mean MUAC in Pre-ART and ART Test groups (i.e. with Amtewa meal) increased by 3.25\% and 5.58\% respectively (Figure 3). This is supported by Chlebowski et al. [37] and Suttmann et al., [38], who demonstrated a 4 and $3 \mathrm{~kg}$ gain in body weight of HIV patients who received nutritional support. Additionally, it has been reported that employing fish oil and fish oil-enriched arginine, HIV patients gained between 1 and $2 \mathrm{Kg}$ fat mass and body weight respectively over a six month period of nutritional support [39].

On the other hand, in the control groups (Pre-ART and ART), as illustrated in Figure 3, there was a decline in the mean MUAC from 28.52 to $27.36 \mathrm{~cm}$ (normal $\geq 23 \mathrm{~cm}$ for male and $\geq 22 \mathrm{~cm}$ for female). However, these values were not suggestive of underweight or malnutrition at the end of the pilot study (i.e. sixth month). This could be attributed to the fact that in the study design, all the groups were given nutritional counseling (Figure 2) in addition to the multivitamin supplementation dispensed to PLWHA receiving care and support at the study centre (SHMCA). The effectiveness of nutritional counseling about protein dietary intake as an intervention to improve health outcomes for HIV positive patients has been reported by Tabi and Vogel [40] whose study; showed increase (from $43.86 \mathrm{~kg}$ to $46.57 \mathrm{~kg}$ for females and from $51.86 \mathrm{~kg}$ to $55.23 \mathrm{~kg}$ for males; $P=0.001$ ) in the mean body weight of Ghanaian patients. Similarly, Van Der Sande et al., [41] showed that one unit decrease of BMI resulted in $21 \%$ increase in mortality rate $(P<0.001)$ after controlling baseline immune status (CD4 count). Therefore nutrition counseling embedded in an intervention program must be sustained to maintain anthropometric parameters (e.g. MUAC, body weight) within normal values and decrease mortality.

\subsection{Other Biomedical Indices}

Patients' median biomedical indices were within the normal range for the following:

- Random glucose (normal range $=140-200 \mathrm{mg} / 100 \mathrm{ml}$ )

- $\operatorname{PCV}$ (normal value $=40 \%$ female, $45 \%$ male) 
- Total protein (normal range $=60-83 \mathrm{~g} / 100 \mathrm{ml})$

- SGOT (normal range $=0-12$ I.U/L)

\subsection{Patients' Compliance}

Patients' compliance was also impressive with over 95\% completing the 6 months trial. This might be explained by 1) the selection of patients willing to proactively undertake a prolonged action that they believed was potentially able to improve the course of their infection; 2) PLWH Aneccessarily attend their hospital appointments monthly or bimonthly for prescription refill and other investigations. Hence, running the intervention programme with Amtewa meal concurrently with the HIV clinic improved compliance.

\section{Conclusion}

Tailored functional recipe approach with Amtewa meal has shown a promising nutritional and immunological response. Therefore, Amtewa meal is deemed innovative, culturally relevant, reliable and requiring low technology to demonstrate physiological and biomedical benefits to PLWH. Although the achieved results take the form of specific technology, it suggests that a prolong consumption of the intervention meal (Amtewa) will be suitable to sustain the gained improvements in MUAC and CD4 cell counts thereby slowing the progression of the disease. These positive outcomes qualified Amtewa meal to the next phase of intervention ( $n=400$ patients) to appraise its position within the National Health Services framework as a useful intervention in attenuating the progression of HIV to AIDS in Nigeria.

\section{Limitations to the Study}

- The employed exclusion criteria (CD4 counts less than 200 cells $/ \mathrm{mm}^{3}$ ) deprived the wider participation of patients with full blown AIDS to be included in the Amtewa meal nutrition intervention.

- The shortage of trained research active/oriented staff was challenging in the health setting particularly nutrition and dietician trained staff.

- Risk of sample contamination (Unintentional collusion between the control and Test group while on HIV care hospital appointments).

\section{References}

[1] World Health Organisation (2006) WHO Case Definitions of HIV for Surveillance and Revised Clinical Staging and Immunological Classification of HIV-Related Disease in Adult and Children. WHO Press, World Health Organisation, Geneva.

[2] AIDS (2009) HIV Life Cycle (Online) AIDS. Gov. http://aids.gov/hiv-aids-basics/just-diagnosed-with-hiv-aids/hiv-in-your-body/hiv-lifecycle/index.html

[3] World Health Organisation (2013) Nutrition Activities in Care, Support and Treatment of HIV/AIDS. Situation Analysis for SEAR Countries Based on Preliminary Desk Review and Inputs from Member Countries (Online). World Health Organisation, Geneva.

http://www.who.int/nutrition/topics/Situation_Analysis_for_SEAR_Countries.pdf

[4] Amlogu, A.M., Godden, K., Tewfik, S., Wambebe, C. and Tewfik, I. (2013) Public Health Nutrition Intervention Programme to Attenuate the Progression of HIV to AIDS among People Living with HIV (PLWH) in Abuja, Nigeria. International Journal of Food, Nutrition \& Public Health (IJFNPH), 6, 83-98.

[5] USAID (2004) Nutrition and HIV/AIDS; Evidence, Gaps and Priority Actions (Online). http://www.fantaproject.org/downloads/.../SARA_Nutrition\&HIV

[6] UNAIDS (2008) Report on the Global Aids Epidemic (Online). http://www.aids2031.org/pdfs/unaids_08executivesummary_en(1).pdf

[7] Anabwani, G. and Nazario, P. (2005) Nutrition and HIV/AIDS in Sub-Saharan Africa; An Overview. The International Journal of Applied and Basic Nutritional Sciences, 21, 96-99.

[8] Federal Ministry of Health (2007) National Guidelines for HIV and AIDS Treatment and Care in Adolescents and Adults. FMOH, Abuja.

[9] WHO (2010) New WHO HIV Treatment and Prevention Guidelines. Available at: www.thelancet.com Vol. 375 March 13,2010 
[10] Pribram, V. (2011) Nutrition and HIV. 1st Edition, Wiley-Blakwell, West Sussex, United Kingdom.

[11] Ivers, L.C., Cullen, K.A., Freedberg, K.A., Block, S., Coates, J. and Webb, P. (2009) HIV/AIDS, Undernutrition, and Food Insecurity. Clinical Infectious Diseases, 49, 1096-1102.

[12] Tewfik, I., Bener, A. and Tewfik, S. (2010) Is Africa Facing a Nutritional Transition under the Double Burden of Disease? World Association for Sustainable Development, Issue 1, 160-171.

[13] UNAIDS (2010) Global Report on the Global AIDS Epidemic 2010. http://www.unaids.org/globalreport/documents/20101123_GlobalReport_full_en.pdf

[14] Amlogu, A.M., Godden, K., Tewfik, S., Wambebe, C. and Tewfik, I. (2012) Tailored Food Recipe-TFR: Employing the European Perspective on Functional Food Science (FUFOSE) to Promote Effective Dietary Intervention in Africa. International Journal of Food, Nutrition \& Public Health, 5, 1-10.

[15] WHO (2005) Executive Summary of a Scientific Review. Consultation on Nutrition and HIV/AIDS in Africa: Evidence, Lessons and Recommendations for Action. Durban, 10-13 April 2005. World Health Organization, 2005, Geneva. http://www.who.int/nutrition/topics/Executive_Summary_Durban.pdf

[16] Hurwitz, B.E., Klaus, J.R., Llabre, M.M., Gonzalez A., Lawrence, P.J., Maher, K.J., Greeson, J.M., Baum, M.K., Shor-Posner, G., Skyler, J.S. and Schneiderman, N. (2007) Suppression of Human Immunodeficiency Virus Type 1 Viral Load with Selenium Supplementation; A Randomized Controlled Trial. Archives of Internal Medicines, 167, 148-154.

[17] Amlogu, M.A., Tewfik, S., Wambebe, C., Godden, K. and Tewfik, I. (2011) Conceptual Framework of Public HealthNutrition Intervention Programme to Attenuate the Progression of HIV to AIDS among People Living with HIV (PLWH) in Abuja, Nigeria. In: Sharing Knowledge Making a Difference: The Role of International Scientific Cooperation, World Sustainable Development Outlook 2011, World Association for Sustainable Development (WASD), London, 11-20.

[18] Drain, P.K., Kupka, R., Mugusi, F. and Fawzi, WW. (2007) Micronutrients in HIV-Positive Persons Receiving Highly Active Antiretroviral Therapy. The American Journal of Clinical Nutrition, 85, 333-345.

[19] Fanta Project (2003) Nutrition and HIV/AIDS: A Training Manual. Nutrition Management of HIV/AIDS Related Symptoms, FANTA, RCQHC and the Linkages Project. http://www.linkagesproject.org/publications/FINAL_NutritionandHIV_manual.pdf

[20] Duggal, S., Chugh, T.D. and Duggal, A.K. (2012) Review Article. HIV and Malnutrition: Effect on Immune System. Journal of Immunology Research, 2012, Article ID: 784740. http://www.hindawi.com/journals/jir/2012/784740/ref/

[21] Piwoz, E.G. and Preble, E.A. (2000) HIV/AIDS and Nutrition: A Review of the Literature and Recommendations for Nutritional Care and Support in Sub-Saharan Africa. SARA Project, Academy for Educational Development/USAID, Washington DC.

[22] Melchior, J.D., Salmon, D., Rigaud, D., Leport, C., Bouvet, E., Detruchis, P., Vilde, L.J., Vachon, F., Coulaud, J.P. and Apfebaum, M. (1991) Resting Energy Expenditure Is Increased in Stable, Malnourished HIV-Infected Patients. American Journal of Clinical Nutrition, 53, 437-441.

[23] FAO/WHO (2002) Living Well with HIV/AIDS-A Manual on Nutritional Care and Support for People Living with HIV/AIDS. Food and Agriculture Organization, Rome. http://www.fao.org/DOCREP/005/Y4168E/Y4168E00.htm

[24] Jones, C.Y., Tang, A.M., Forrester, J.E., Huang, J.Y., Hendricks, K., Knox, T.A., Spiegelman, D., Semba, R.D. and Woods, M.N. (2006) Micronutrient Levels and HIV Disease Status in HIV-Infected Patients on Highly Active Antiretroviral Therapy in the Nutrition for Healthy Living Cohort. Journal of Acquired Immune Deficiency Syndrome, 43, 475-482. http://dx.doi.org/10.1097/01.qai.0000243096.27029.fe

[25] WHO (2009) Nutritional Care and Support for People Living with HIV/AIDS: A Training Course. World Health Organization, Geneva. http://www.who.int/nutrition/publication/hivaids

[26] WHO (2003) Nutrient Requirements for People Living with HIV/AIDS: Report of a Technical Consultation. WHO, Geneva.

[27] Piwoz, E. (2004) Nutrition and HIV/AIDS: Evidence, Gaps and Priority Actions. The Support for Analysis and Research in Africa Project. Academy for Education Development, Washington DC, 49, 190-195.

[28] FANTA (2004) HIV/AIDS: A Guide for Nutritional Care and Support. 2nd Edition, Food and Nutrition Technical Assistance Project, Academy for Educational Development, Washington DC. http://www.fantaproject.org/publications/HIVguide.shtml

[29] Roberfroid, M.B. (2000) Concepts and Strategy of Functional Food Science: The European Perspective. American Journal of Clinical Nutrition, 71, 1660S-1664S.

[30] Kumar, P. and Clark, M. (2005) Clinical Medicines. 6th Edition, Elsevier Saunders, London. 
[31] Boon, N.A. and Walker, B.R. (2006) Davidson’s Principle and Practice of Medicines. 20th Edition, Elsevier, Philadelphia.

[32] Fawzi, W.W., Msamanga, G.I., Kupka, R., Spiegelman, D., Villamor, E., Mugusi, F., Wei, R. and Hunter, D. (2007) Multivitamin Supplementation Improves Hematologic Status in HIV-Infected Women and Their Children in Tanzania. American Journal of Clinical Nutrition, 85, 1335-1343.

[33] UNAIDS and WHO (2009) AIDS Epidemic Update. UNAIDS/09.36E/JC1700E (English Original, November 2009), UNAIDS, Geneva.

[34] Committee on Medical Aspects of Food Policy (COMA) (1991) Report on Health and Social Subjects. 41 Dietary Reference Values for Food Energy and Nutrients for the United Kingdom. HMSO.

[35] Paton, N.I., Sangetha, S., Earnest, A. and Bellany, R. (2006) The Impact of Malnutrition on Survival and the CD4 Count Response in HIV-Infected Patients Starting Antiretroviral Therapy. British HIV Association, HIV Medicine, 7, 323-330. http://dx.doi.org/10.1111/j.1468-1293.2006.00383.x

[36] Kaiser, J.D., Campa, A.M., Ondercin, J.P., Leoung, G.S., Pless, R.F. and Baum, M.K. (2006) Micronutrient Supplementation Increases CD4 Count in HIV-Infected Individual on Highly Active Antiretroviral Therapy: A Prospective, Double-Blinded, Placebo-Controlled Trial. Journal of Acquired Immune Deficiency Syndromes, 42, 523-528. http://dx.doi.org/10.1097/01.qai.0000230529.25083.42

[37] Chlebowski, R.T., Beall, G., Grosvenor, M., Lillington, L., Weintraub, N., Ambler, C., Richards, E.W., Abbruzzese, B.C., McCamish, M.A. and Cope, F.O. (1993) Long-Term Effects of Early Nutritional Support with New Enterotropic Peptide-Based Formula vs. Standard Enteral Formula in HIV-Infected Patients: Randomized Prospective Trial. Nutrition, 9, 507-512.

[38] Süttmann, U., Ockenga, J., Selberg, O., Hoogestraat, L., Deicher, H. and Müller, M.J. (1995) Incidence and Prognostic Value of Malnutrition and Wasting in Human Immunodeficiency Virus-Infected Outpatients. Journal of Acquired Immune Deficiency Syndromes \& Human Retrovirology, 8, 239-246. http://dx.doi.org/10.1097/00042560-199503010-00004

[39] Pichard, C., Sudre, P., Karsegard, V., Yerly, S., Slosman, D.O., Delley, V., Purrin, L., Hirschel, B. and the Swiss HIV Cohort Study (1998) A Randomised Double-Blind Controlled Study of 6 Months of Oral Nutritional Supplementation with Arginine and $\Omega-3$ Fatty Acids in HIV-Infected Patient. AIDS, 12, 53-63. http://dx.doi.org/10.1097/00002030-199801000-00007

[40] Tabi, M. and Vogel, R.L. (2006) Nutritional Counseling: An Intervention for HIV Positive Patients. Journal of Advanced Nursing, 54, 676-682. http://dx.doi.org/10.1111/j.1365-2648.2006.03855.X

[41] Van Der Sande, M.A.B., Van der Loeff, M.F.S., Aveika, A.A., Sarge-Njie, R., Alabi, A.S., Jaye, A., Corrah, T. and Whittle, H.C. (2004) Body Mass Index at Time of HIV Diagnosis: A Strong and Independent Predictor of Survival. Journal of Acquired Immune Deficiency Syndromes, 37, 1288-1294. http://dx.doi.org/10.1097/01.qai.0000122708.59121.03 
Scientific Research Publishing (SCIRP) is one of the largest Open Access journal publishers. It is currently publishing more than 200 open access, online, peer-reviewed journals covering a wide range of academic disciplines. SCIRP serves the worldwide academic communities and contributes to the progress and application of science with its publication.

Other selected journals from SCIRP are listed as below. Submit your manuscript to us via either submit@scirp.org or Online Submission Portal.
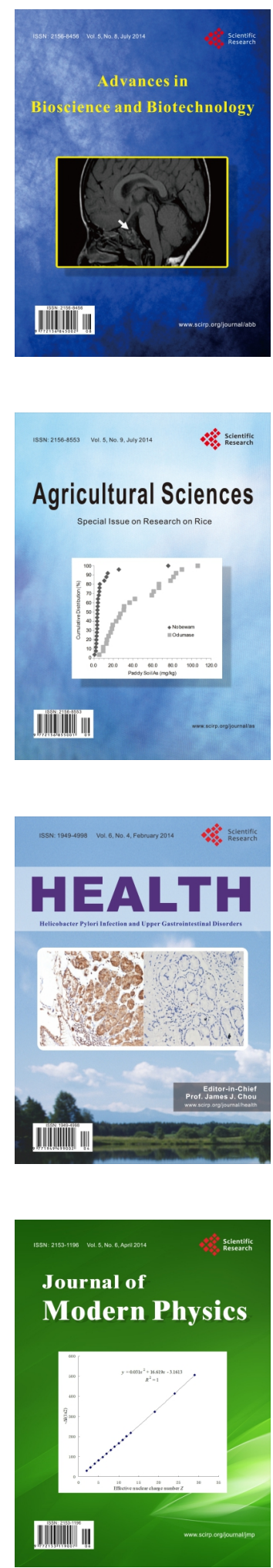
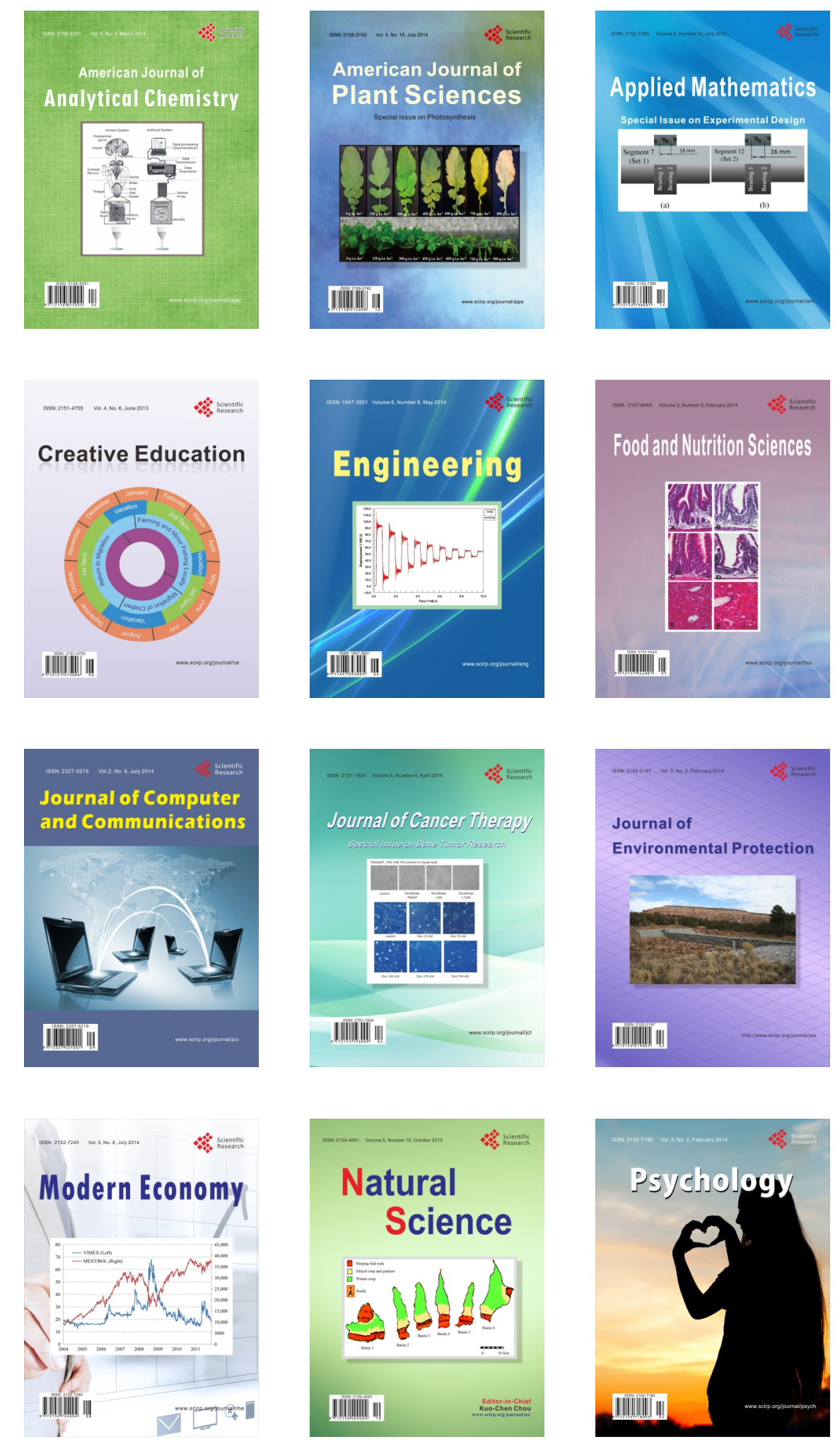